\title{
Selection of Most Suitable Candidates for the Talent Pool in a Furniture Manufacturing Company
}

\section{Izbor najtalentiranijih kandidata u tvrtki za proizvodnju namještaja}

\author{
Preliminary paper • Prethodno priopćenje \\ Received-prispjelo: 11. 1. 2016. \\ Accepted-prihvaćeno: 6. 9. 2016. \\ UDK: 634 (075); 630*836.1 \\ doi:10.5552/drind.2016.1601
}

\begin{abstract}
This paper deals with the question of identification and development of talents in the company. The aim of the article is to find one of the possible solutions to increase the objectivity of identifying talents and finding valuable input data for planning effectively their further development. The objective is achieved by estimates of the weights of criteria and by the multicriteria decision making method. The proposed model for solving this problem is specific for companies in furniture industry, as well as for companies in other sectors. For this reason, the selected methods have been applied to a specific example of the Czech company operating in furniture industry for over twenty years.
\end{abstract}

Key words: talent, talent pool, furniture industry, multicriteria decision, talent management

SAŽETAK・Pitanje identifikacije i razvoja talenata u tvrtki trenutačno je jedna od tema o kojoj se najviše raspravlja. Cilj članka bio je pronaći jedno od mogućih rješenja za povećanje objektivnosti identifikacije talenata i pronalaženja vrijednih ulaznih podataka za učinkovito planiranje njihova daljnjeg razvoja. Taj se cilj postiže procjenom težine kriterija i metodom višekriterijskog odlučivanja. Predloženi model rješenja tog problema specifičan je za poduzé́a koja proizvode namještaj, ali se može primijeniti i u drugim sektorima. Izabrane metode primijenjene su na predlošku češke tvrtke koja posluje u industriji proizvodnje namještaja dulje od dvadeset godina.

Ključne riječi: talent, grupa talenata, proizvodnja namještaja, višekriterijsko odlučivanje, upravljanje talentima

\section{INTRODUCTION 1. UVOD}

Talent management is not a new concept. The talent management concept was introduced around the 1990s and became popular with McKinsey“s War for Talent survey in 1997 (Maycock and Ikuomola, 2015). The subject of discussion in scientific articles is mainly defined and understood as the extent of integration of talent management (Sojka, 2013) with the "strategy of the company as well as resolving the lack of talents in general" (Stephan et al., 2014). The problem is not just the lack of talents, but difficult identification to create a talent pool in the organization, as well as efficient planning of their training and development (Grenčíková et al. 2015).

Experts engaged in searching talents are hesitant since companies should be more focused on identify-

\footnotetext{
${ }^{1}$ Author are assistant at Department of Tourism and Marketing, Institute of Technology and Business in České Budějovice, Czech Republic. ${ }^{2}$ Author are associate professor at Faculty of Wood Science and Technology, Technical University of Zvolen, Slovakia.

${ }^{1}$ Autor je asistent Odjela za turizam i marketing Instituta tehnologije i trgovine, České Budějovice, Češka Republika. ${ }^{2}$ Autor je izvanredni profesor Fakulteta znanosti o drvu i drvne tehnologije, Tehničko sveučilište u Zvolenu, Zvolen, Slovačka.
} 
ing and developing talents (Briscoe and Hall, 1999). The investment in learning and development of talents (Garavan et al. 2012) has been justified as a source of competitive advantage. Garavan (2012) concluded that external talent acquisition strategy has proven to be unsuccessful in the long run with many organisations (Merková et al., 2013). Lepak and Snell (1999) and Stacho and Stasiak-Betlejewska (2014) determined relative advantage of organisations developing their workforce internally. In their article, Maycock and Ikuomola (2015) show that it is more efficient to focus on talents within the company (use internal resources) and then to invest in their training and development (Hitka and Štípalová, 2011). It opens serious questions in the practical implementation of company's talent management (Stacho et al., 2013):

- Who is the talent for the company and what type of talent the company needs?

- How can a talent be properly identified and developed?

- What will be the return of the cost of the talent pool for the company?

- How to motivate the talent pool for further learning and development?

\subsection{Identification of talents}

1.1. Identifikacija talenata

Lukáč (2009) defines talent as a combination of skills, personal qualities and qualifications, which are enriched by the potential of their further development. According to the CIPD (2007), Kropivšek et al. (2011) and Kucharčíková (2014), talented individuals are the ones who can highly contribute to the performance of the company by immediate contributing to the performance or longer-term demonstration of high potential. Hitka and Lejsková (2015) indicate that, in practice, the problem area of talent management (the processes of talent management is shown in Fig. 1) is insufficient setting of talents, as well as its imprecise definition of the competencies required for talent pooling (Farkašová et.al., 2013). The next problem area determined as defective is the wrong choice of a talent for the company based on set criteria (competencies), which usually results in an irretrievable investment. Therefore, the key element (Kampf et al., 2014) in identifying talents in a company is to define the required and needed competencies (selection criteria). These competencies should be in accordance with the business strategy (Sojka, 2013) and this way to ensure the effectiveness of the selection of talents in the organization for their further use in the company as key personnel. Authors Ali Taha and Sikorová (2012), Bolfíková et al. (2010) and Nováková (2011) discuss the following areas of competencies (criteria):

- behavioral aspects (for example: „I can - I will do“),

- knowledge, skills and abilities,

- soft skills,

- cognitive skills (eg. diversity of thought),

- experiences,

- recognized values.

Every company has its own characteristics (Weberova, 2013) and specificities to be taken into account in determining competencies. In view of this fact, it is natural that some of the required competencies have higher weight (are more important) than other competencies (Olexová et al., 2011). When identifying talents (Hitka et al., 2013), it is not only important to determine what competencies are expected from talents, but also to define their priority. (Zámečník, 2014). From this perspective, it is possible to comprehensively assess candidates when building a talent pool (Kampf et al., 2015). When evaluating workers in search of talents, different methods are used (Rebeták and Farkašová, 2015; Lukáč, 2009):

1. Assessment of previous performances and achieved objectives;

2. References of senior staff;

3. Evaluation $360^{\circ}$ (inside the organization) or $540^{\circ}$ (outside the company, in the form of verification of references);

4. In-depth structured interview;

5. Performance and other tests;

6. Assessment and Development Centre, Leadership Assessment.

The quality of the assessment depends on the emphasis on objectivity and takes into account the costs that the company plans to invest in the talent pool for the future.

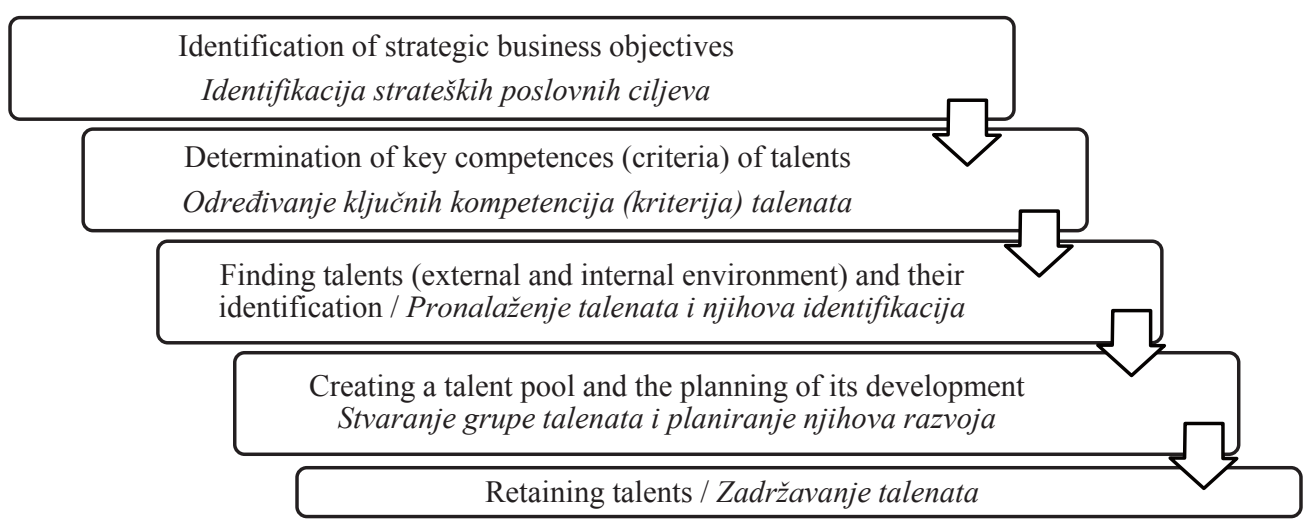

Figure 1 Talent management processes in the company

Slika 1. Procesi upravljanja talentima u poduzeću 


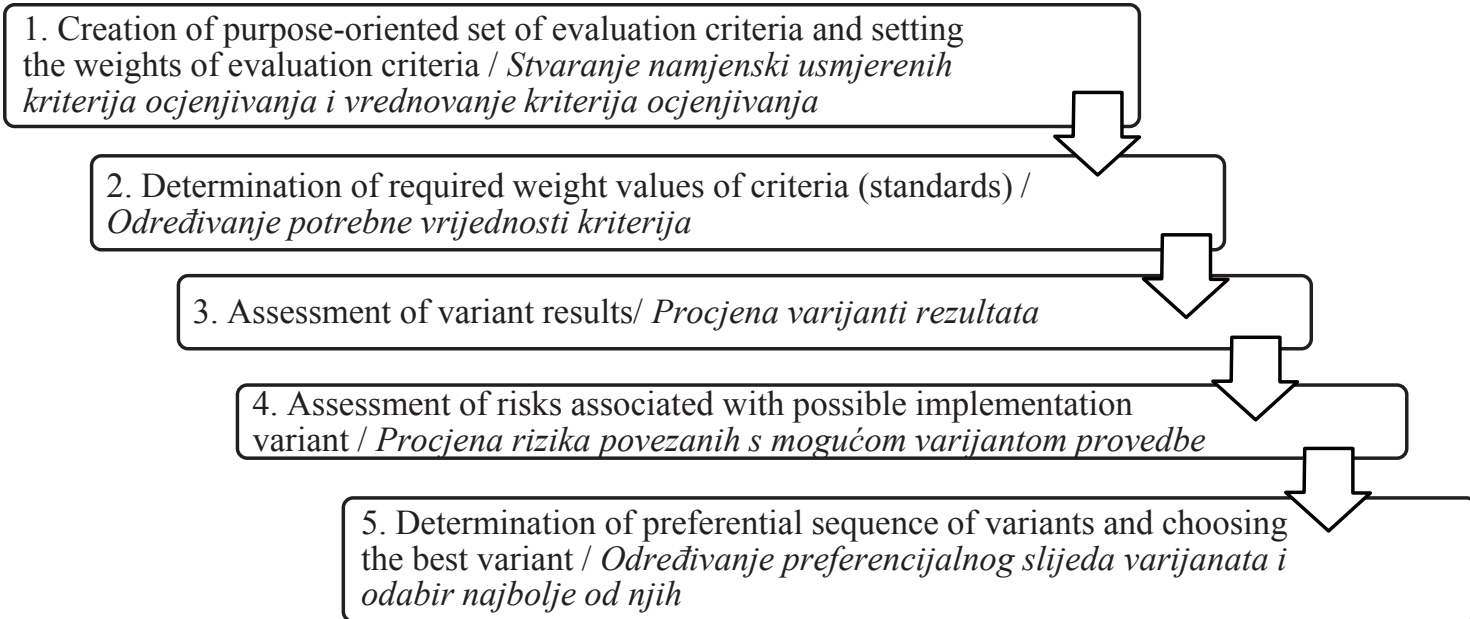

Figure 2 The steps of using multicriteria decision method (Clemen, 1991)

Slika 2. Koraci u primjeni višekriterijskog odlučivanja (Clemen, 1991.)

\section{MATERIAL AND METHODS 2. MATERIJAL I METODE}

The aim of the article is to find one of the possible solutions to increase the objectivity of identifying talents in the company and finding valuable input data for effective planning of their further development. The objective is achieved by estimating the weights of criteria and by using the method of multicriteria decision making.

The suitability of methods for optimizing the selection of talent pool will be considered based on the type of input data to be processed and usability conclusions of optimization method. Using methods of multicriteria decision, the sequence of steps shown in Fig. 2 must be respected. The selected methods have been applied to a specific example of the Czech company operating in furniture industry with a twenty-year tradition.

\subsection{Methods for determining criteria weightings 2.1. Metode određivanja težine kriterija}

For accurate diagnosis and selection of talents in the company, it is necessary to clearly determine the required competence. Due to the limited selection resulting from a lack of talents, the company should consider the prerequisites of candidates for obtaining some competencies. It requires categorizing competencies with respect to their weight of importance in accordance with the strategy of the company. It is often difficult to obtain weight importance in numerical form. For this reason, the use of estimates of weights of the criteria will facilitate the assessment of the evaluators. The best known methods (Jablonský, 2002) are the Method of Ranking, Scoring Method, Method of Fuller Triangle and Saaty's Method. The method of ranking and scoring method are based on direct evaluation criteria (Stopka et al., 2014). In the method of ranking, the evaluator sets ranking of most important criteria (assigning a value $k$, where $k$ is the number of criteria), from the most important $k-1, k-2 \ldots$ to the least important, which is assigned a value of 1 . Consequently, as the assigned value $\mathrm{i}$-th criterion is marked as $p_{i}$, it is possible to estimate scales (Eq. 1) by calculating (Jablonský, 2002):

$$
v_{i}=\frac{p_{i}}{\sum_{i=1}^{k} p_{i}} i=1,2, \ldots, k
$$

The requirement that the evaluator can qualitatively evaluate the importance of the pre-determined scoring scale (eg. 1 to 10) is essential for the suitability of the scoring method. The higher the score, the higher importance will be placed on that criterion. If the value assigned $i$-th criterion is denoted as $p$, it is possible to weight the criteria calculated according to Eq. 1. These methods are not entirely favorable for the evaluator because clear assessment criteria are less accurate and do not reflect the relationships of criteria with each other. Methods based on pairwise comparison criteria are more appropriate for the solution of the question of talents identification. Principle Fuller triangle is based on mutual comparison criteria arranged in a triangular scheme (Fig. 3), where each pair occurs only once. The evaluator selects important criterion of each pair (Jablonský,

\begin{tabular}{|c|c|c|c|c|}
\hline Y1 & $\begin{array}{l}\mathrm{Y} 1 \\
\mathrm{Y} 3\end{array}$ & Y1 & $\begin{array}{l}Y 1 \\
\mathbf{Y} 5\end{array}$ & $\begin{array}{l}\text { Y1 } \\
Y 6\end{array}$ \\
\hline \multirow{8}{*}{ Y2 } & $\mathrm{Y} 2$ & Y2 & Y2 & Y2 \\
\hline & Y3 & Y4 & Y5 & Y6 \\
\hline & & Y3 & Y3 & Y3 \\
\hline & & Y4 & Y5 & Y6 \\
\hline & & & Y4 & Y4 \\
\hline & & & Y5 & Y6 \\
\hline & & & & Y5 \\
\hline & & & & Y6 \\
\hline
\end{tabular}

Figure 3 The scheme of the Fuller's Triangle Method (Jablonsky, 2002)

Slika 3. Shema metode Fullerova trokuta (Jablonsky, 2002.) 
2002), and highlights it. Unless both criteria are of equal importance, the evaluator will highlight both. Subsequently, the evaluator calculates the number of highlighted $i$-th criteria identified as $p$ and obtains an estimate of the weights criteria according to Eq. 1.

Saaty's method (Saaty, 2008) is the most sophisticated of the described methods and allows for broader consideration of the impact of preference criteria based on pair comparison. The degree (Jablonský, 2002) of importance of the criteria $v$ is assessed on a scale from 1 to 9 , where value 1 indicates that the criteria are of equal importance and value 9 expresses the absolute preference of one criterion to another. If the first criterion is less important than the other, this relationship is expressed by the inverse of the scales (1/1-9). Consequently, the final evaluation can be entered in Saaty's matrix, where each element $S_{i j}(E q .2-4)$ can be obtained as the ratio of estimating of weights for the $i$-th and $j$-th criterion (Saaty, 2000):

$$
\begin{aligned}
& s_{\mathrm{i}} \approx \frac{v_{\mathrm{i}}}{v_{\mathrm{j}}}(i, j=1,2,3, \ldots . k) \\
& v_{i}=\left(\prod_{j=1}^{k} s_{i j}\right)^{1 / k} i=1,2, \ldots, k, k \\
& v_{i}=\frac{v_{i}^{\prime}}{\sum_{i=1}^{k} v_{i}^{\prime}} i=1,2, \ldots, k
\end{aligned}
$$

Substituting the calculated elements (Saaty, 1988) of the matrix into the Eq. 3 and 4 allows for calculating the weighting of importance of the particular criteria. Saaty's method is the most appropriate form of determining (Kampf et al., 2012) the weighting of criteria for the purposes of identifying the talent pool in the particular furniture company, since it respects the complicated relationships between individual criteria. Based on the obtained weightings, it is possible to assess the suitability of each candidate and reduce the complexity and frequent inaccuracies of evaluators' decision. As input data, utilization of the results of assessment and development centre, where several evaluators can imitate the conditions to fulfill the criteria of individuals, who are subjected to multiple types of tasks, seems to be the optimal decision. This evaluation fulfils the condition of the comprehensive evaluation.

\subsection{Methods based on selecting the most suitable} variant

2.2. Metode utemeljene na odabiru najprikladnije varijante

There are a lot of methods for selecting the most suitable variant within multi-criteria analysis and they are based on different principles (Filová et al., 2012). The most common methods are AHP method (Analytic Hierarchy Process), ELECTRE methods PROMETHEE method, WSA method, the complex utility function method, TOPSIS method and others (Klaric et al.,2015) (Kampf, 2003). In this paper, the AHP method has been selected. It is based on the principle of paired comparisons of elements in each level of a hierarchical structure. This represents a model of the particular decision-making problem. Given the objectives of the paper, this method is selected to obtain the cardi- nal information and accessibility for the evaluators, due to the possibility of using the verbal evaluation.

\section{RESULTS}

3. REZULTATI

\subsection{Application of Saaty's method to conditions of a specific company operating in furniture industry}

3.1. Primjena Saatyjeve metode u uvjetima konkretne tvrtke koja posluje u industriji proizvodnje namještaja

Practical application of Saaty's method in this article is to evaluate the importance of the required criteria of talents in a company of furniture industry. Companies producing furniture have some specific features (Mateides and Ďad'o, 2002, Greger et. al., 2013). Taking into account these specifics, it will become possible to increase the efficiency in the management of their talents. The specifics that affect the business strategy of companies of furniture industry are mainly determined by the nature of their product. These specifics are transformed into the production process and situation in furniture trade (Potkány and Giertl, 2014). Managers have to be able to identify these specific features and take them into account. The example has been made on the basis of the data found in a Czech company, manufacturing furniture for over 20 years. Determination and subsequent valuation criteria discussed in this example were obtained in 2015 from the five key managers (the values given are arithmetic average). In accordance with the objectives and strategies of the company, the key criteria (competencies) were determined:

K1 - ability to work under stress / sposobnost rada pod stresom

K2 - analytical and logical thinking / analitičko $i$ logično razmišljanje

K3 - creativity and openness to new ideas / kreativnost $i$ otvorenost prema novim idejama

K4 - expertise (expertise in furniture production field) / stručnost

K5 - communication skills / komunikacijske vještine

K6 - team thinking / timsko razmišljanje

K7 - reliability and responsibility / pouzdanost $i$ odgovornost

K8 - experience / iskustvo

K9 - ability to react flexibly to changes / sposobnost fleksibilne reakcije na promjene

K10 - purposefulness / svrhovitost.

Based on these defined competencies for identifying talents in the organization and assessment of their importance by paired comparison (Eq. 2), Saaty's matrix could be made. It is presented in Tab. 1.

The values of obtained weights K1 - K10 determine the importance of the required competencies for the talent. These weights can be used for decision making in the selection of talents in several ways. The simplest and the most commonly used method, in practice, is rating (Tab. 2). The resulting values of rating are obtained by multiplying the assessment of candidate competencies $\left(V_{\mathrm{j}}\right)$ and the value of the criteria weight $\left(K_{\mathrm{i}}\right)$. The matrix was tested for consistency (CR 
Table 1 Calculation of criteria weights by using the Saaty's matrix

Tablica 1. Izračun vrednovanja kriterija uz pomoć Saatyjeve matrice

\begin{tabular}{|c|c|c|c|c|c|c|c|c|c|c|c|c|}
\hline $\begin{array}{c}\text { Criterion } \\
\text { Kriterij }\end{array}$ & $\mathbf{K 1}$ & $\mathbf{K 2}$ & $\mathbf{K 3}$ & $\mathbf{K 4}$ & $\mathbf{K 5}$ & $\mathbf{K 6}$ & $\mathbf{K} 7$ & $\mathbf{K 8}$ & $\mathbf{K 9}$ & $\mathbf{K 1 0}$ & $\boldsymbol{v}_{\mathbf{i}}$ & $\boldsymbol{v}_{\mathbf{i}}$ \\
\hline $\mathbf{K 1}$ & 1 & 1.40 & 7.00 & 8.20 & 0.36 & 2.40 & 1.40 & 7.80 & 1.80 & 2.20 & 2.225067 & 0.169436 \\
\hline $\mathbf{K 2}$ & 0.71 & 1 & 2.40 & 7.00 & 0.33 & 3.40 & 1.20 & 6.40 & 2.00 & 4.00 & 1.957774 & 0.149082 \\
\hline $\mathbf{K 3}$ & 0.14 & 0.42 & 1 & 4.80 & 0.13 & 0.90 & 3.00 & 7.80 & 0.39 & 1.40 & 0.920863 & 0.070122 \\
\hline $\mathbf{K 4}$ & 0.12 & 0.14 & 0.21 & 1 & 0.12 & 0.37 & 0.13 & 2.00 & 0.28 & 0.55 & 0.304126 & 0.023159 \\
\hline $\mathbf{K 5}$ & 2.80 & 3.03 & 7.46 & 8.13 & 1 & 3.20 & 2.40 & 7.60 & 2.20 & 1.40 & 3.137958 & 0.238951 \\
\hline K6 & 0.42 & 0.29 & 1.12 & 2.70 & 0.31 & 1 & 1.40 & 7.00 & 2.20 & 1.60 & 1.148321 & 0.087443 \\
\hline K7 & 0.71 & 0.83 & 0.33 & 7.46 & 0.42 & 0.71 & 1 & 8.40 & 1.80 & 2.00 & 1.295477 & 0.098649 \\
\hline K8 & 0.13 & 0.16 & 0.13 & 0.50 & 0.13 & 0.14 & 0.12 & 1 & 0.16 & 0.12 & 0.188370 & 0.014344 \\
\hline K9 & 0.56 & 0.50 & 2.56 & 3.59 & 0.45 & 0.45 & 0.56 & 6.28 & 1 & 1.80 & 1.127485 & 0.085856 \\
\hline K10 & 0.45 & 0.25 & 0.71 & 1.82 & 0.71 & 0.63 & 0.50 & 8.13 & 0.56 & 1 & 0.826767 & 0.062957 \\
\hline
\end{tabular}

$=0.096)$. According to Saaty (2000), the permissible tolerance is $\max .10 \%$, therefore the consistency condition is satisfied.

The input data (obtained score of competencies of candidates $-\mathrm{V}_{\mathrm{j}}$ ) are in this case obtained by means of development centre and $360^{\circ}$ evaluations (Tab. 2). Candidates $(n=6)$ were evaluated by five evaluators, who rated the range of 1-9 (where 1 - very poor, 9 very strong). The resulting value is the average of the assessment of all evaluators.

Another option of decision making is AHP method, based on the principle of Saaty's matrix. In making use of Saaty's matrix, the candidates are compared (Eq. 2) for each criterion in a separate matrix (Tab. $3)$. The advantage of this method is more comprehensive assessment of deviations between meeting individual criteria. A comparison of the candidates for each criterion in a single matrix is shown in Table 3 . The values in the matrix are obtained based on the ratio of compared assessment of candidates to the selected criterion (Eq. 2). Thus obtained results for individual candidates are used to calculate the final evaluation of the candidates as shown in Table 4.

The method of rating is a quick option for obtaining rapid and relatively acceptable results. Tab. 2 shows this recalculation for each criterion of the monitored candidates (V1 -V6). The fields marked in grey show the highest values for the evaluated criteria. Consequently, it is possible to determine the final evaluation of candidates and their sequence of suitability. The three best ratings of candidates are marked in grey. In this case, the most suitable candidates are V2, V4 and V1.

The maximum calculated values obtained by using the resulting weights of candidates and the criteria (Table 4) are highlighted in bold. Based on the sum of preferential index values of each candidate, the optimum sequence can be determined in identifying talents in the organization. In this case, the optimal candidate is V2, and V4 is the second, which corresponds to the rating of the first method (Table 2).

The resulting sequence obtained by the AHP method differs in the determination of other suitable candidates, namely: V6 is the third most optimal candidate (in Table 2 it is V1), followed by V3, V1 and V5.

\section{DISCUSSION AND CONCLUSION 4. RASPRAVA I ZAKLJUČAK}

Using the estimate of weights methods for each criterion in identifying talents improves the quality of talent selection. It this article, Saaty's method is evaluated as the most appropriate method. The application of

Table 2 Evaluation of candidates and recalculation by weight of criteria (rating)

Tablica 2. Ocjenjivanje kandidata i izračun vrijednosti kriterija (ocjena)

\begin{tabular}{|c|c|c|c|c|c|c|c|c|c|c|c|c|c|}
\hline \multirow[t]{2}{*}{$\begin{array}{l}\text { Criterion } \\
\text { Kriterij }\end{array}$} & \multicolumn{6}{|c|}{$\begin{array}{c}\text { Evaluation of candidates } \\
\text { Ocjenjivanje kandidata }\end{array}$} & \multirow{2}{*}{$\begin{array}{l}\text { Weight of } \\
\text { criteria } \\
\text { Vrijednost } \\
\text { kriterija }\end{array}$} & \multicolumn{6}{|c|}{$\begin{array}{c}\text { Candidate evaluation recalculatiion by criteria } \\
\text { weight / Preračunavanje ocjenjivanja kandidata } i \\
\text { vrijednosti kriterija }\end{array}$} \\
\hline & V1 & $\mathrm{V} 2$ & V3 & V4 & V5 & V6 & & V1 & V2 & V3 & V4 & V5 & V6 \\
\hline K1 & 7.4 & 3.6 & 2.8 & 8.0 & 5.4 & 6.2 & 0.169436 & 1.254 & 0.610 & 0.474 & 1.355 & 0.915 & 1.051 \\
\hline $\mathrm{K} 2$ & 8.0 & 6.0 & 8.2 & 7.4 & 5.0 & 4.6 & 0.149082 & 1.193 & 0.894 & 1.222 & 1.103 & 0.745 & 0.686 \\
\hline K3 & 3.4 & 7.2 & 6.4 & 4.2 & 8.2 & 3.0 & 0.070122 & 0.238 & 0.505 & 0.449 & 0.295 & 0.575 & 0.210 \\
\hline K4 & 8.0 & 6.0 & 2.8 & 5.4 & 2.8 & 8.4 & 0.023159 & 0.185 & 0.139 & 0.065 & 0.125 & 0.065 & 0.195 \\
\hline K5 & 3.2 & 7.0 & 6.0 & 4.2 & 3.2 & 5.4 & & 0.765 & 1.673 & 1.434 & 1.004 & 0.765 & 1.290 \\
\hline K6 & 4.6 & 7.6 & 6.0 & 5.2 & 4.6 & 5.0 & 0.087443 & 0.402 & 0.665 & 0.525 & 0.455 & 0.402 & 0.437 \\
\hline K7 & 7.0 & 6.8 & 3.6 & 7.4 & 7.2 & 8.4 & & 0.691 & 0.671 & 0.355 & 0.730 & 0.710 & 0.829 \\
\hline K8 & 7.8 & 7.4 & 3.8 & 4.0 & 7.0 & 8.4 & 0.014344 & 0.112 & 0.106 & 0.055 & 0.057 & 0.100 & 0.120 \\
\hline K9 & 7.4 & 7.4 & 8.0 & 8.4 & 8.2 & 5.0 & 0.085856 & 0.635 & 0.635 & 0.687 & 0.721 & 0.704 & 0.429 \\
\hline K10 & 4.6 & 5.2 & 5.8 & 5.4 & 3.6 & 8.0 & 0.062957 & 0.290 & 0.327 & 0.365 & 0.340 & 0.227 & 0.504 \\
\hline \multicolumn{8}{|c|}{ Total score / Ukupan rezultat } & 5.764 & 6.225 & 5.631 & 6.185 & 5.208 & 5.751 \\
\hline \multicolumn{8}{|c|}{ Sequence / Redoslijed } & 3 & 1 & 5 & 2 & 6 & 4 \\
\hline
\end{tabular}


Table 3 Conversion of candidates' suitability by AHP method

Tablica 3. Izračun prikladnosti kandidata primjenom AHP metode

\begin{tabular}{|c|c|c|c|c|c|c|c|c|c|c|c|c|c|c|c|c|c|}
\hline K1 & $V 1$ & V2 & V3 & $\mathrm{V4}$ & V5 & V6 & $v_{i}$ & $v_{\mathrm{i}}$ & K6 & V1 & V2 & V3 & V4 & V5 & V6 & $v_{i}$ & $v_{\mathrm{i}}$ \\
\hline $\mathrm{V1}$ & 1 & 2.06 & 64 & 93 & 37 & 19 & 42060 & 2215 & V1 & 1 & 0.61 & .77 & 0.88 & 1.00 & .92 & 85019 & 13939 \\
\hline $\mathbf{V 2}$ & . & 1 & 29 & & 07 & & & & 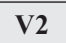 & & 1 & 27 & 6 & 55 & 52 & & 23030 \\
\hline V3 & 0.38 & 78 & 1 & 0.35 & 0. & & 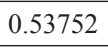 & & V3 & & 品 & & 5 & 0 & & 4 & 8182 \\
\hline V4 & .08 & 22 & 2.86 & 1 & 1.48 & 1.29 & 3578 & 0.23952 & V4 & 3 & 0.68 & - & 1 & 1.13 & .04 & 0.96108 & 15758 \\
\hline V5 & .73 & 50 & 1.93 & 0.68 & 1 & 0.87 & 3665 & 16168 & 5 & 0 & 0.61 & 77 & 0.88 & 1 & 92 & 0.85019 & 13939 \\
\hline V6 & 0.84 & 72 & 2.21 & .78 & 15 & 1 & 19023 & 0.185 & V6 & 9 & 0.66 & 33 & 0.96 & 19 & 1 & 92412 & 15152 \\
\hline K2 & V1 & V & V3 & V4 & $\mathbf{V}$ & V6 & $v_{i}^{\prime}$ & $v_{\mathrm{i}}$ & K7 & V1 & 2 & 3 & V4 & 5 & V6 & $v_{i}^{\prime}$ & $v_{\mathrm{i}}$ \\
\hline V1 & 1 & 1.33 & 0.98 & 1.08 & 1.60 & 1.74 & 25532 & 0.20408 & - & 1 & 1.03 & 1.94 & 0.95 & 0.97 & 0.83 & 1.07392 & 17327 \\
\hline V2 & 07 & 1 & 73 & 0.81 & 20 & 0 & 149 & 6 & $\mathrm{~V} 2$ & 0.97 & 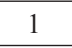 & 1.89 & 0.92 & 4 & 1 & 4 & 832 \\
\hline V3 & 1.03 & 1.37 & 1 & 1. & 1.64 & 1.78 & 70 & 0. & $\mathbf{v}$ & & 0.53 & 1 & 0.49 & 50 & 43 & 0.55230 & 08911 \\
\hline $\mathrm{V4}$ & 0.93 & 1.23 & 0.90 & 1 & 1.48 & 1.61 & 1.16117 & 0.18878 & V4 & 1.06 & 1.09 & 2.06 & 1 & 1.03 & 0.88 & 1.13529 & 0.18317 \\
\hline V5 & 63 & 83 & . 61 & 0.68 & 1 & 1.09 & 78457 & 2755 & V5 & 1 & 1.06 & .00 & 0.97 & 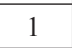 & 0.86 & .10460 & 17822 \\
\hline V6 & 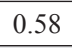 &  & 0.56 & 0.62 & 0.92 & 1 & 72181 & 0.11735 & & & & & 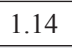 & & & 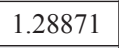 & 0792 \\
\hline K3 & V1 & $\mathbf{V}$ & V3 & V4 & V5 & $\mathrm{V}$ & $i_{i}$ & $i_{i}$ & K8 & & & 3 & V4 & 5 & & & $v_{i}$ \\
\hline V1 & 1 & 0.47 & 0.53 & 0.81 & 0.41 & 1.13 & 0.67600 & 0.10494 & V1 & 1 & 1.05 & 2.05 & 1.95 & 1.11 & 0.93 & 1.27841 & 0.20313 \\
\hline V2 & .12 & 1 & 1.13 & 1.71 & 0.88 & 2.40 & 1.43154 & 0.22222 & V2 & 0.95 & 1 & 1.95 & 1.85 & 1.06 & 0.88 & 1.21285 & .19271 \\
\hline V3 & 1.8 & & 1 & 1.5 & 0.78 & 2 & 248 & 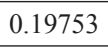 & & & 0.51 & & 0.95 & & 0.45 & 62281 & 896 \\
\hline $\mathrm{V4}$ & & & & 1 & & & & & & & & & & & & & 417 \\
\hline V5 & 2.41 & 1.14 & 1.28 & 1.95 & 1 & 2.73 & 1.63036 & 0.25309 & $\mathrm{Vs}$ & 0.90 & 0.95 & 1.84 & 1.75 & 1 & 0.83 & 1.14729 & 0.18229 \\
\hline V6 & 0.88 & 0.42 & 0.47 & 0.71 & 0.37 & 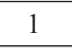 & 0.59647 & 0.09259 & V6 & 1.08 & 1.14 & 2.21 & 2.10 & 1.20 & 1 & 1.37675 & .21875 \\
\hline K4 & V1 & $\mathrm{V} 2$ & V3 &  & V5 & Ve & $v_{i}^{\prime}$ & $v_{\mathrm{i}}$ & K9 & V1 & $\mathrm{V} 2$ & V3 & V4 & V5 & V6 & $v_{i}^{\prime}$ & $v_{\mathrm{i}}$ \\
\hline V1 & 1 & 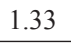 & 2 & & & & & & & 1 & & & 0 & & & & 6667 \\
\hline $\mathbf{V 2}$ & 0.75 & 1 & 14 & 1.11 & 2.14 & & 8244 & & $\mathrm{~V} 2$ & & 1 & 0.93 & 88 & .90 & 1.70 & & .16667 \\
\hline V3 & 0.35 & 0.47 & 1 & 0.52 & 1.00 & 0.33 & 0.55181 & 0. & V3 & 1.08 & 1.08 & 1 & 0.95 & 0.98 & 1.60 & 1.09645 & .18018 \\
\hline V4 & 0.68 & 0.90 & 1.93 & 1 & 1.93 & 0.64 & 1.06420 & 0.16168 & V4 & 1.14 & 1.14 & 1.05 & 1 & 1.02 & 1.68 & 1.15127 & .18919 \\
\hline V5 & 0.35 & 0.47 & 1.00 & 0. & 1 & 0.33 & 0.55181 & 0.08 & V5 & & 1.11 & 1.03 & 98 & - & 1.64 & 1.12386 & 0.18468 \\
\hline V6 & 1.05 & 1.40 & 3.00 & 1.56 & 3.00 &  & 1.65542 & 0.25150 & 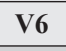 & 0.68 & 0.68 & 0.63 & 0.60 & 0.01 & 1 & .68528 & .11261 \\
\hline K5 & V1 & $\mathrm{V} 2$ & V3 & V4 & V5 & $\mathrm{VG}$ & $v_{i}^{\prime}$ & $v_{\mathrm{i}}$ & K10 & V1 & $\mathrm{V} 2$ & & V4 & V5 & V6 & & $v_{\mathrm{i}}$ \\
\hline V1 & 1 & 0.46 & 0.53 & 0.76 & 1.00 & 0.59 & 0.69228 & 0.11034 & V1 & 4 & 0.88 & 0.79 & 0.85 & 1.28 & 0.58 & 0.87182 & 14110 \\
\hline $\mathbf{V 2}$ & 2.19 & 1 & 1.17 & 1.67 & 2.19 & 1.30 & 1.51437 & 0.24138 & V2 & & 1 & 0.90 & 0.96 & 1.44 & 0.65 & 0.98554 & 0.15951 \\
\hline V3 & 1.88 & 0.86 & 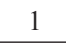 & 1.43 & 1.88 & 1.11 & 1.29803 & 0.20690 & $\sqrt{5}$ & 1.26 & 1.12 & 1 & 1.07 & 1.61 & 0.73 & 1.09926 & 0.17791 \\
\hline V4 & 1.31 & 0.60 & 0.70 & 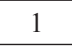 & 1.31 & 0.78 & 0.90862 & 0.14483 & V4 & 1.17 & 1.04 & 0.9 & 1 & 1.50 & 0.68 & 1.02345 & 0.16564 \\
\hline V5 & 1.00 & 0.46 & 0.53 & 0.76 & 1 & 0.59 & 0.69228 & 0.11034 & V5 & 0.78 & 0.69 & 0.62 & 0.67 & 1 & 0.45 & 0.68230 & .11043 \\
\hline V6 & 1.69 & 0.77 & 0.90 & 1.29 & 69 & 1 & 1.16823 & 21 & V6 & 1.74 & 1.54 & 1.38 & 1.48 & 2.22 & 1 & 1.5 & 0.2 \\
\hline
\end{tabular}

Table 4 Resulting suitability variants by AHP method

Tablica 4. Izračun prikladnosti pojedinih inačica primjenom AHP metode

\begin{tabular}{|c|c|c|c|c|c|c|c|c|c|c|c|c|c|}
\hline \multirow{2}{*}{$\begin{array}{c}\text { Crite- } \\
\text { rion } \\
\text { Krite- } \\
r i j\end{array}$} & \multicolumn{6}{|c|}{ Weights of the candidates $\left(v_{\mathbf{p}}\right) /$ Vrijednosti kandidata $\left(v_{i}\right)$} & \multirow{2}{*}{$\begin{array}{c}\text { Weight } \\
\text { of } \\
\text { criteria } \\
\text { Vrijed- } \\
\text { nost } \\
\text { kriterija }\end{array}$} & \multicolumn{6}{|c|}{$\begin{array}{c}\text { Preferential index of variations }\left(\mathbf{w}_{\mathrm{ji}}\right) / \text { Preferencijalni } \\
\text { indeks varijanti }\left(w_{j i}\right)\end{array}$} \\
\hline & V1 & V2 & V3 & V4 & V5 & V6 & & V1 & V2 & V3 & V4 & V5 & V6 \\
\hline K1 & 0.22156 & 0778 & 08383 & 3952 & 16168 & 0.18563 & 0.16944 & 0.03754 & 26 & 0.01420 & 0.04058 & 0.02739 & 0.03145 \\
\hline K2 & & & 20918 & & & & & 2 & & 9 & 0.02814 & 02 & 0.01749 \\
\hline K3 & 0.10494 & 2222 & 0.19753 & 3 & 309 & 0.0 & 0.1 & 0.00736 & 0.0 & 0.01 & 0.00909 & 0.01775 & 0.00649 \\
\hline K4 & 0.23952 & 17964 & 0.08383 & 0.16168 & 0.08383 & 0.25150 & 0.02316 & 0.00555 & 0.00 & 0.00194 & 0.00374 & 0.00194 & 0.00582 \\
\hline K5 & & & 0.20690 & & 034 & 0.1 & $\mathbf{0 .}$ & 0.02 & 68 & 0.04944 & 0.03461 & 637 & 0.04449 \\
\hline K6 & 0.1 & 030 & 0.18182 & 58 & 939 & 0.15152 & 744 & 0.01219 & 0.02014 & 0.01590 & 0.01378 & 0.01219 & 0.01325 \\
\hline K7 & 0.17327 & 0.16832 & 0.08911 & 0.18317 & 0.17822 & 0.20792 & 0.09865 & 0.01709 & 0.01660 & 0.00879 & 0.01807 & 0.01758 & 0.02051 \\
\hline K8 & & & 0. & & & & & 0.0 & 76 & 0.0 & 0.00149 & 0.00261 & 0.00314 \\
\hline K9 & 0.16667 & 667 & 0.18018 & 0.18919 & 0.18468 & 0.11261 & 0.0 & 0.01431 & 0.01431 & 0.01547 & 0.01624 & 0.01586 & 0.00967 \\
\hline K10 & 0.14110 & 0.15951 & \begin{tabular}{|l|l|}
0.17791 \\
\end{tabular} & 0.16564 & 0.11043 & 0.24540 & 0.06296 & 0.00888 & 0.01004 & 0.01120 & 0.01043 & 0.00695 & 0.01545 \\
\hline \multicolumn{8}{|c|}{$\mathrm{u}\left(\mathrm{X}_{\mathrm{i}}\right)$ Total benefit of variations / Ukupna korist varijante $\left(\sum v_{j}=1,000\right)$} & 0.16263 & 0.18236 & 0.16340 & 0.17618 & 0.14766 & 0.16777 \\
\hline \multicolumn{8}{|c|}{ Sequence of preference / Redoslijed izbora } & 5 & 1 & 4 & 2 & 6 & 3 \\
\hline
\end{tabular}


Saaty's method is shown in the real case of talent selection in the Czech company operating in furniture industry. The accuracy of selection can be optimized by selecting the appropriate method for determining the correct option (the candidate) based on several criteria.

AHP methods were compared based on Saaty's matrix with simple rating (multiplying assessment of candidates and weight of criteria). Different ranking of candidates was obtained by using these methods. Divergence of results was caused by detailed paired comparison of competencies of individual candidates. The need for planning development and training of identified talents was associated with increased costs, creating a need for an optimized selection. Optimized selection of candidates can be inaccurate particularly in the case of:

- changes in priorities and objectives of furniture manufacturer,

- inaccurate or biased assessment of candidates, by the evaluators,

- incorrect or incomplete consideration of the required competencies.

The aim of the article was to find opportunities to improve the quality of decision-making when identifying talents in a furniture manufacturing company. For this reason, the determining of criteria for choosing talents has to be established in view of specific production process and company objectives. These requirements also depend on the character and situation in the furniture market. To meet the set target, several methods could be used to estimate the weights of the criteria. Saaty's method was determined as the most appropriate in view of obtaining cardinal information that can be further used. In this article, AHP method was chosen for identifying the best option, which allows a comparison of the candidates on the basis of verbal evaluation by several experts. Another reason was that AHP method was to provide accurate outputs that can form the basis for further targeted development planning of talents. The use of these optimization methods provides the accuracy of the results obtained and the subsequent decisions represent a reduction in investment risk for the development of the talent pool.

\section{REFERENCES}

\section{LITERATURA}

1. Ali Taha, V.; Sikorová, M., 2012: The nature and importance of talent management in the organization. In: Proceedings of scientific works of the department of economics and the economy ANNO 2012 [electronic resource], pp. 15-24.

2. Bolfíková, E.; Hrehová, D.; Frenová, J., 2010: Manager's decision-making in organizations-Empirical analysis of bureaucratic vs. learning approach. Zbornik radova Ekonomskog fakulteta u Rijeci, 28 (1): 135-163.

3. Briscoe, J. P.; Hall, D. T., 1999: An alternative approach and new guidelines for practice. Organizational Dynamics, 28 (2): 37-52.

https://doi.org/10.1016/S0090-2616(00)80015-7.

4. Cartered Institute of Personal and Development (CIPD), 2007: Learning and development. [10.8.2015]. Available on: http://www.cipd.co.uk/NR/rdonlyres/EB18FA28BD40-4D47-81B9-660034D280C1/0/learndevsr.pdf.

5. Clemen, R. T., 1991: Making hard decisions: An introduction to decision analysis. Boston: PWS Kent.

6. Farkasova et al., 2013: Managerial roles in the current business environment. In: Globalization and its socioeconomic consequences, 13 refereed proceedings of the international conference. Žilina: University, p. 121-128.

7. Filová, E.; Dávid A.; Sosedová, J., 2012: Multi-criteria analysis in the assessment methodology centers of tourism. Transport and communication-electronic magazine of the Faculty of Operation and Economics of Transport and Communications University of Žilina, vol. 2012.

8. Garavan, T. N.; Carbery, R.; Rock, A., 2012: Mapping talent development: definition, scope and architecture. In: European Journal of Training and Development, 36 (1): 5-24. https://doi.org/10.1108/03090591211192601.

9. Greger, K.; Šegotić, K.; Grladinović, T.; Bičanić, K.; Perić, I., 2013: Rangiranje kriterija pri utvrđivanju sposobnosti tehnološkog procesa u proizvodnji namještaja. Šumarski list, 137 (5-6): 279-285.

10. Grenčíková, A.; Španková, J.; Karbach, R., 2015: Current trends in enterprise employment policies in Slovak Republic. Actual Problems of Economics, 170 (8): 293301.

11. Hitka, M.; Lejsková, P., 2015: Increasing efficiency of enterprise management employees' careers. VŠTE v ČB.

12. Hitka, M.; Štípalová, L., 2011: Comparing of Employees Motivation Level in Enterprises of Wood Working Industry with other Manufacturing Enterprises in Slovak Republic. Drvna industrija, 62 (3): 185-192. https://doi.org/10.5552/drind.2011.1101.

13. Hitka, M.; Vetráková, M.; Gražulis, V.; Kampf, R.; Hajduková, A., 2013: Performance improvement of staff. Zvolen, Technical University in Zvolen.

14. Jablonský, J., 2002: Operations research, quantitative models of economic. Praha: Professional Publishing.

15. Jelačić, D. et al., 2010: Motivation factors analysis in industrial plants. Strojarstvo, 52 (3): 349-361.

16. Kampf, R., 2003: Multiple criteria decision-WSA method. In: Scientific papers of the University of Pardubice. Series B (8/2002).

17. Kampf, R.; Hitka, M.; Potkány, M., 2014: Interannual differences in employee motivation in manufacturing enterprises in Slovakia. Communications, Žilina: University of Zilina, 16 (4): 98-102.

18. Kampf, R.; Ližbetin, J.; Ližbetinová, L., 2012: Requirements of a transport system user. Communications, Žilina: University of Zilina, 2012 (4).

19. Kampf, R.; Ližbetinová, L., 2015: The Identification and Development of Talents in the Environment of Logistics Companies. Naše more, 62 (3) (Special Issue): 139-142.

20. Klarić, K.; Grladinović, T.; Šegotić, K.; Greger, K.; Grošelj, P.; Klarić, M., 2015: Identification of Key Factors of TQM: Application of AHP and PROMETHEE Methods. Proceedings of $26^{\text {th }}$ International Conference on Wood Science and Technology (ICWST), Zagreb, Croatia.

21. Kropivšek, J.; Jelačić, D.; Grošelj, P., 2011: Motivating employees of Slovenian and Croatian wood industry companies in times of economic downturn. Drvna industrija, 62 (2): 97-103.

https://doi.org/10.5552/drind.2011.1040.

22. Kucharčíková, A., 2014. The importance of identification and analysis of educational needs for investment in human capital. Komunikacie, 16 (3): 86-92.

23. Lepak, D. P.; Snell, S. A., 1999: The human resource architecture: Toward a theory of human capital allocation 
and development. Academy of management review, 24 (1): 31-48. https://doi.org/10.2307/259035.

24. Lipušček, I. et al., 2010: A multi-criteria decision-making model for classifying wood products with respect to their impact on environment. Int. j. life cycle assess., 15 (4): 359-367. https://doi.org/10.1007/s11367-010-0157-6

25. Lukáč, M., 2009: Talent management from the perspective of performance management employees. In the development of personal potential (s. p. 3). Amrop Hever Slovakia - Global Executive Search.

26. Mateides, A.; Dado, J., 2002: Services. Theory of services; marketing services; quality of service; customer service and satisfaction measurement with them. EPOS. Economic consultancy.

27. Maycock, E. A.; Ikuomola, O. A., 2015: Learning and talent development: a review in context. In: International Journal Of Advanced Research in Engineering \& Management (IJAREM), pp. 98-111.

28. Merková, M.; Drábek, J.; Jelačić, D., 2013: Application of Risk Analysis in Business Investment Decision-Making. Drvna industrija, 64 (4): 313-322. https://doi.org/10.5552/drind.2013.1317.

29. Nováková, R., 2011: Scientific-Research Cluster as a form of Knowledge Transfer. Drvna industrija, 62 (4): 291-300. https://doi.org/10.5552/drind.2011.1120

30. Oblak, L. et al., 2006: The comparison of the coating systems according to the basis criteria. Wood research, 51 (4): 77-86.

31. Olexová, C.; Bašistová, P.; Mesároš, A., 2011: Priorities of human resources management in knowledge. In: Business Trends $1 / 2011$ - scientific journal of the Faculty of Economics UWB.

32. Potkány, M.; Giertl, G., 2014: Comparison of selected performance indicators of woodworking industry in the Czech Republic and Slovakia. 7th International Scientific Conference on Position and Role of the Forest Based Sector in the Green Economy: Proceedings of scientific papers, Zvolen: Slovakia, pp.131-138.

33. Rebeták, M.; Farkašová, V., 2015: Managing High-Potential Employees. Procedia Economics and Finance, (23): 867-871. https://doi.org/10.1016/S2212-5671(15)00437-2

34. Saaty, T. L., 1988: Mathematical models for decision support. Springer Berlin Heidelberg.

35. Saaty, T. L., 2000: Fundamentals of decision making and priority theory with the analytic hierarchy process. Rws Publications.
36. Saaty, T. L., 2008: Decision making with the analytic hierarchy process. In: International journal of services sciences, 2008 (1.1): 83-98.

https://doi.org/10.1504/ijssci.2008.017590

37. Sojka, L., 2013: Principles and practices of talent management. Journal of Management and Business: Research and Practice.

38. Stacho, Z.; Stasiak-Betlejewska, R., 2014: Approach of organisations operating in Slovakia to employee's performance evaluation. Institute of Society Transformation, Economic Annals-XXI, 5-6: 82-85.

39. Stacho, Z.; Urbancová, H.; Stachová, K., 2013: Organisational arrangement of human resources management in organisations operating in Slovakia and Czech Republic. Acta Universitatis Agriculturae et Silviculturae Mendelianae Brunensis, LXI (7), 2787-2799. http://dx.doi.org/10.11118/actaun201361072787.

40. Stephan, M.; Walkinshaw, H.; Vahdat, H.; Walsh, B., 2014. Talent analytics in practice. In: Global Human Capital Trends 2014: Engaging the 21st-century workforce Deloitte Consulting LLP and Bersin by Deloitte, pp. 117-126.

41. Stopka, O.; Kampf, R.; Koláŕ, J.; Kubasaková, I.; Savage, C., 2014: Draft guidelines for the allocation of public logistics centres of international importance. Communications, 2014 (2).

42. Weberova, D., 2013: The process of effective communication in project management. 1st ed. Zlín: VeRBuM.

43. Zámečník, R., 2014: The measurement of employee motivation by using multi-factor statistical analysis. Procedia-Social and Behavioral Sciences, (109): 851-857. https://doi.org/10.1016/j.sbspro.2013.12.553.

\section{Corresponding address:}

Ing. LENKA LIŽBETINOVÁ, PhD.

The Institute of Technology and Business in České

Budějovice

Department of Tourism and Marketing

Okružní 517/10,

37001 České Budějovice

e-mail: lizbetinova@mail.vstecb.cz 